\title{
Correction to: The efficacy of an extraoral scavenging device on reduction of splatter contamination during dental aerosol generating procedures: an exploratory study
}

The original article can be found online at https://doi.org/10.1038/s41415-020-2112-7

Research Br Dent J 2020; 229: https://doi.org/10.1038/s41415-020-2112-7

The article The efficacy of an extraoral scavenging device on reduction of splatter contamination during dental aerosol generating procedures: an exploratory study, written by Shakeel Shahdad, Tulsi Patel, Annika Hindocha, Neil Cagney, Jens-Dominik Mueller, Noha Seoudi, Claire Morgan \& Ahmed Din, was originally published electronically on the publisher's internet portal on 11 September 2020 without open access due to a problem during production. The copyright is (c) The Author(s), under exclusive licence to British Dental Association 2020 and the article is distributed under a Creative Commons Attribution 4.0 International License, which permits use, sharing, adaptation, distribution and reproduction in any medium or format, as long as you give appropriate credit to the original author(s) and the source, provide a link to the Creative Commons licence, and indicate if changes were made. The images or other third party material in this article are included in the article's Creative Commons licence, unless indicated otherwise in a credit line to the material. If material is not included in the article's Creative Commons licence and your intended use is not permitted by statutory regulation or exceeds the permitted use, you will need to obtain permission directly from the copyright holder. To view a copy of this licence, visit http://creativecommons.org/licenses/by/4.0. 